\author{
Blanka Tundys \\ University of Szczecin \\ e-mail:blanka.tundys@usz.edu.pl \\ ORCID: 0000-0002-6026-7060
}

\title{
SUSTAINABLE SUPPLY CHAIN MANAGEMENT - PAST, PRESENT AND FUTURE
}

\section{ZARZĄDZANIE ZRÓWNOWAŻONYM LAŃCUCHEM DOSTAW - PRZESZLOŚĆ, TERAŹNIEJSZOŚĆ I PRZYSZLOŚĆ}

DOI: $10.15611 / \mathrm{pn} .2020 .3 .15$

JEL Classification: Q5, M3, R4

\begin{abstract}
Summary: Sustainable supply chain management has been an issue in both literature and business practice since the 1990s. Both the development phases and the definition range (including the complexity and number of individual processes) have been subject to changes and modifications over the years. The multitude of definitions and theoretical scope is a barrier to the implementation of the concept in economic practice. The aim of this paper is to show how it has evaluated the concept and thematic scope in theoretical point of view and in relation to its practical implementation. The research was carried out using content analysis methods, as well as selected case studies. The most important findings include: a presentation and change in the understanding and application of SSCM; bibliometric analysis with an interpretation of the state, volume and scope of SC research; directions and trends in research including the identification of research gaps that may be a basis for further research.
\end{abstract}

Keywords: sustainable supply chain management, theory, praxis, bibliometrics.

Streszczenie: Zarządzanie zrównoważonym łańcuchem dostaw stanowi istotny problem badawczy zarówno w literaturze, jak i w praktyce biznesowej od lat dziewięćdziesiątych $\mathrm{XX}$ wieku. Zakres definicyjny, w tym złożoność procesów, elementów i funkcji, na przestrzeni lat ulegały znacznym modyfikacjom. Mnogość i wieloznaczność definicji stanowi barierę we wdrażaniu koncepcji w praktyce gospodarczej. Celem niniejszego opracowania jest wskazanie, w jaki sposób interpretowano zakres zarządzania zrównoważonym łańcuchem dostaw. Badania zostały przeprowadzone $\mathrm{z}$ wykorzystaniem metod bibliometrycznych i analizy treści, a także wybranych studiów przypadków. Do najważniejszych wyników należy zaliczyć: prezentację zakresu definicyjnego, w tym ewaluację interpretacji pojęcia, dogłębną analizę bibliometryczną z interpretacją stanu, wielkości i zakresu badań nad zielonymi i zrównoważonymi łańcuchami dostaw; kierunki i trendy $w$ badaniach i wdrażaniu praktycznych rozwiązań w tym obszarze, w tym identyfikację luk badawczych, które mogą stanowić podstawę dalszych badań nad tą strategią łańcucha dostaw.

Słowa kluczowe: zarządzanie zrównoważonym łańcuchem dostaw, teoria, praktyka, analiza bibliometryczna. 


\section{Introduction}

\subsection{Statement of the problem}

Discussions on sustainable supply chain management have been conducted by scientists since the 1990s. It is also a practical area where copies and solutions are reflected in the configurations and strategies of today's supply chains. The interest in this subject is related, among others, to the fact that more and more companies are recognized as those responsible for environmental, social and economic impacts, which are the results of the internal activities of business organizations and their supplier (Hartmann and Moeller, 2014). The basis for sustainable supply chain management is therefore the integration and implementation of social, economic and environmental sustainability objectives into the chain strategy.

The challenge in developing and implementing this type of strategy is certainly the geographical distance that separates individual links in the chain, as well as the position of individual units in the entire chain structure (Koberg and Longoni, 2019). It is also possible to identify barriers to the implementation of the SSCM concept related to the three basic areas of sustainable development and their understanding. Different expectations may be related to cultural differences (Wu and Pullman, 2015), and lack of transparency in chains (including among suppliers or sub-suppliers from developing countries where the environment is understood and protected differently and regulations are not always properly enforced) (Carter, Rogers, and Choi, 2015).

Literature analysis indicates that not only is the interest in the above topics constantly growing, which is justified by the growing number of scientific publications in this area, but also the research area and the research methods used are changing (in the sense of enlargement). More and more often, scientists use advanced modelling tools to present issues in this area, including decision support, multi-criteria methods, and at the same time there are very useful publications writing about practical solutions implemented in specific sectors or chain leaders. The indicated duality allows for a wide range of topics and the formulation of conclusions and recommendations for the future for a wide audience.

\subsection{Objectives, research gaps and thesis}

The aim of the discussion is to indicate how the approach to sustainable supply chain management has changed, which areas were highlighted and which were omitted in the initial phase of the strategy development, how the concept development influenced the configuration of chains, to which industry the new strategy most often refers, and in which direction the strategy will develop. Practical solutions were also referred to, as well research gaps. The most important question is: has the perception and understanding of Sustainable Supply Chain Management (SSCM) strategy changed 
over the years and what are the future directions of research and practical solutions for SSCM?

In addition to the objectives and research questions, a basic thesis can be formulated indicating that the observed trends and changes in defining, describing relationships between individuals, understanding and configuring a sustainable supply chain are related to the increasing importance given to the sustainable development of global economies, and the growing awareness of people, including supply chain managers. This knowledge indicates that the activities and processes taking place in chains have a direct negative impact on the natural environment, but also on other areas of sustainable development. It therefore seems reasonable to assume that the greater the scope and diversity of sustainable development activities, mechanisms and concepts introduced into the supply chain strategy, the more environmentally friendly and sustainable these chains will be.

\section{Sustainable supply chain management - theoretical background and literature review}

A sustainable supply chain is defined as the management of materials, information and capital flows and cooperation between companies along the supply chain, while meeting the objectives of the three dimensions of sustainability (economic, social, environmental), which are derived from customer and stakeholder requirements (Seuring and Müller, 2008). Ahi and Searcy ( 2013) assume that sustainable supply chain management means creating coordinated supply chains through the voluntary integration of economic, environmental and social aspects with internal business systems. It also means designing them to effectively and efficiently manage materials, information and capital flows, which in turn are related to the procurement and distribution of products or services in order to meet the needs of stakeholders, improve profitability and the competitiveness of the company.

The design of such a chain focuses on the voluntary integration of social, economic and environmental aspects into business systems, leading to a coordinated supply chain concept to effectively manage materials, information and capital associated with logistics processes, in order to improve the profitability of flows. Such a chain is pro-environmental and at the same time is a source of long-term profit. (Pagell and Wu, 2009). Tseng et al. (Tseng, Lim, and Wong, 2015) defined a catalogue of factors determining the functioning of a sustainable supply chain, including: "green" warehousing, strategic cooperation with suppliers, environmental protection, continuous improvement, use of information technologies, optimization of logistic processes, internal pressure, institution-new pressure, social and ethical values, corporate strategy and commitment, economic stability, design of green ecological products, social pressure, increased customer expectations, image of the organization, legal regulations, competitive pressure, and the shortage of natural resources. 
Citing Kisperska-Moron (2012), it can be pointed out that the pressure of balancing in the supply chain does not only consist in creating and implementing pro-social and pro-ecological activities, which may be able to support the economic results (or at least not harm them). On the contrary, the three aspects of sustainability indicate to managers the necessity to undertake such actions which improve economic results and at the same time allow for the implementation of social and environmental objectives. Thus, sustainable development, and in particular sustainable supply chain management, involves the long-term improvement of the economic performance of economic organisations. It can be concluded that such an approach meets the requirements of modern business, focusing on economic aspects, while at the same time it is possible to meet other requirements, which are, among other things, a reflection of the growing pressure of consumers. In addition to social, environmental and economic issues, sustainable chain management stimulates good corporate governance practices throughout the product life cycle. The need to involve all links and the cooperation of all actors in the chain is an important sign. Each link can fulfil its sustainability commitments in a different way and to its own extent. However, the greatest responsibility lies with the producers, who can have the greatest impact on the environment and the creation of appropriate attitudes by the chain's participants (Tundys, 2018).

\subsection{Sustainable supply chain management - past and present}

The environmental aspects of logistics and supply chain have been of interest to researchers since the 1990s. The emerging work concerned related elements of the supply chain, supply chain management, logistics itself, and individual processes (e.g. procurement and greening).

The first sources of scientific literature publications on sustainable supply chain date back to 2000 (Fung, Morton, and Chong, 2000) and 2001 (Pulkki, 2001). In both cases, interest in the subject matter has been identified, but this has not yet been indicated as part of a new supply chain strategy. The first publications as well as the definitions refer rather to the interest in pollution and, at the same time, environmental sustainability. The conclusions of both publications boil down to the fact that the interest in sustainability in the supply chain must relate to minimising environmental impacts, and the costs of supply chain operations, whilst increasing quality, value and benefits for society. It is already clear that this goes beyond the scope of only the environment, although the first publications do not yet define a new business strategy. This happens in the second phase of the development of interest in sustainable supply chains. (The interest of scientists in a given area is presented in Table 1). As shown in Table 1, the increase in publications (and thus also scientific interest) in this area started around 2008. The interest of researchers is growing and the scope and type of publications are changing. There are considerations that can be divided into four types: presenting definitions and SSCM 
areas, models (especially mathematical and econometric), presenting and using tools and instruments for SSCM research and case studies. The literature review in this area has included, among others Ansari and Kant (2017). Two concepts of supply chain are distinguished in the considerations - Sustainable Supply Chain (SSC) and Sustainable Supply Chain Management (SSCM). These are not the same concepts. The analysis was conducted for both concepts separately and for selected aspects in both areas.

Table 1. Number of publications covering SSC and SSCM topics (2000-2019)

\begin{tabular}{|c|c|c|c|c|c|c|c|c|c|}
\hline \multirow{2}{*}{ Year } & \multicolumn{2}{|c|}{$\begin{array}{l}\text { Sustainable } \\
\text { supply chain } \\
\text { management }\end{array}$} & \multicolumn{2}{|c|}{$\begin{array}{l}\text { Sustainable } \\
\text { supply chain }\end{array}$} & \multirow{2}{*}{ Year } & \multicolumn{2}{|c|}{$\begin{array}{l}\text { Sustainable } \\
\text { supply chain } \\
\text { management }\end{array}$} & \multicolumn{2}{|c|}{$\begin{array}{l}\text { Sustainable } \\
\text { supply chain }\end{array}$} \\
\hline & Scopus & $\begin{array}{l}\text { Web of } \\
\text { Science }\end{array}$ & Scopus & $\begin{array}{l}\text { Web of } \\
\text { Science }\end{array}$ & & Scopus & $\begin{array}{l}\text { Web of } \\
\text { Science }\end{array}$ & Scopus & $\begin{array}{l}\text { Web of } \\
\text { Science }\end{array}$ \\
\hline 2000 & 0 & 1 & 2 & 3 & 2010 & 22 & 10 & 56 & 20 \\
\hline 2001 & 1 & 0 & 1 & 0 & 2011 & 23 & 15 & 65 & 31 \\
\hline 2002 & 0 & 0 & 2 & 0 & 2012 & 31 & 19 & 90 & 36 \\
\hline 2003 & 2 & 0 & 3 & 1 & 2013 & 47 & 22 & 102 & 43 \\
\hline 2004 & 1 & 0 & 4 & 0 & 2014 & 65 & 41 & 156 & 86 \\
\hline 2005 & 0 & 0 & 0 & 1 & 2015 & 67 & 59 & 171 & 108 \\
\hline 2006 & 2 & 0 & 7 & 2 & 2016 & 100 & 73 & 198 & 128 \\
\hline 2007 & 2 & 3 & 13 & 6 & 2017 & 113 & 101 & 234 & 189 \\
\hline 2008 & 16 & 13 & 28 & 16 & 2018 & 164 & 142 & 329 & 251 \\
\hline 2009 & 11 & 9 & 32 & 16 & $2019 * *$ & 110 & 74 & 233 & 137 \\
\hline
\end{tabular}

** to August 2019.

Source: own elaboration on the data base Scopus and Web of Science (August, 2019).

It can be pointed out that the breakthrough years were 2007 and 2008. At that time, the most important works that still form the basis of SSCM considerations today were published. An in-depth study and characterisation of early interest in the subject matter is presented by Seuring and Müller (2008). The same authors also published a conceptual framework for sustainable supply chain management (see: Seuring and Müller, 2008). Since then more and more publications have been published to define the scope of a sustainable supply chain. Definitional aspects include the following: (Carter and Rogers, 2008; Seuring, 2008; Ciliberti, Pontrandolfo, and Scozzi, 2008; Font, Tapper, Schwartz, and Kornilaki, 2008; Pagell and Wu, 2009; Wolf, 2011; Closs, Speier, and Meacham, 2011; Ahi and Searcy, 2013; Pagell and Shevchenko, 2014; Karthik, Raut, Kamble, Kharat, and Kamble, 2015).

The literature review of the study indicates that there is no consensus on a definition of a sustainable supply chain (as well as sustainable supply chain management). The wide range of principles and elements related to sustainability contributes to a wide range of application possibilities in the supply chain, covering 
a broad range of subject areas (in terms of processes, operations, activities, relationships and linkages between the various entities making up the supply chain) (see: Schaltegger, Burritt, Beske, and Seuring, 2014; Spetic, Marquez, and Kozak, 2012).

After the phase related to the definition of the concept and thematic scope (Touboulic and Walker, 2015), the authors focused on the use of quantitative scientific tools, including the most popular ones related to multi-criteria decisions, to develop statistical, econometric and mathematical models that support the creation, functioning and evaluation of sustainable supply chains and their individual processes (e.g. selection of a supplier, etc.), cf. (Sasikumar and Kannan, 2009; Brandenburg, Govindan, Sarkis, and Seuring, 2014).

Subsequently, there appeared publications indicating sets of measures and indicators to assess the functioning of a sustainable supply chain or its individual processes. Most often performance and practice measurements based on 3BL classics are performed. Within the framework of the considerations, the measurement refers to: Environmental Management Practices, Socially Inclusive Practice, Operations Practices, Supply Chain Integration. An important element of measurement is performance: environmental, social, operations and competitiveness (see: Das, 2017; Chardine-Baumann and Botta-Genoulaz, 2014). An extensive analysis of the measurement of the sustainable and green supply chain can be found in: Tundys and Wiśniewski, 2018; Tundys, Rzeczycki, Zioło, and Jankowski, 2014; Ahi and Searcy, 2015; Hassini, Surti, and Searcy, 2012; Hervani, Helms, and Sarkis, 2005; Popović, n.a.; Tajbakhsh, Hassini, 2015), and also about sustainable indicators in: (Moreno-Camacho, Montoya-Torres, and Jaegler, 2019) and drivers (Tundys, 2018; Sarkar and Pansera, 2017). Considerable attention is also paid to the choice of supplier (Faisal, Al-Esmael, and Sharif, 2017; Fallahpour, Udoncy, Nurmaya, Yew, and Noori, 2017) and the practical aspects (Jaegler and Sarkis, 2015) or applying the principles of sustainable development in particular processes.

From the point of view of decision-making and process approach, it can be pointed out that most publications refer to supplier selection (here both in terms of green and sustainable supply chain), see: (Wu and Barnes, 2015; Zhou and Xu, 2018).

Today, authors are increasingly focusing on applying specific principles of a sustainable supply chain strategy to the implementation of specific solutions in specific industries (Beske, Land, and Seuring, 2014), or developing a sustainable chain strategy (Harms, Hansen, and Schaltegger, n.a.). In 2017 [Rajeev, Pati, Podhi, and Govindan, 2017] described, on the basis of literature on the subject, the evolution and development of sustainable supply chains and the state of the current knowledge on sustainable supply chains management. In the latest publications, more and more often the subject of a sustainable supply chain is connected with the use of the advanced methods: multi-criteria, statistical or mathematical to make decisions within the chain, as well as in the assessment of its functioning and indicating its application in particular industries (see: Ghadimi, Dargi, and Heavey, 2017; Lu, 
Jiang, Song, and Ming, 2018; Alamdar, Rabbani, and Heydari, 2018; Kiousis, Nathanail, and Karakikes, 2019; Zahiri, Zhuang, and Mohammadi, 2020).

An increasing number of publications on the implementation of sustainable development principles can be found using the examples of particular countries or geographical regions (see: Freiboth, 2018; Varsei and Polyakovskiy, 2017) to systematise the literature in this area (Koberg and Longoni, 2019). A characteristic feature of the current publications, despite the lack of clarity in defining the concept, is the lack of considerations relating precisely to the definition of the area, scope, and processes within the chains that occur in the strategy of a sustainable supply chain and its management.

Table 2. Analysis of the number of SSC and SSCM publications in the context of the main research directions (2000-2019)

\begin{tabular}{|l|c|c|c|c|}
\hline \multirow{2}{*}{} & \multicolumn{2}{|c|}{ SSC } & \multicolumn{2}{c|}{ SSCM } \\
\cline { 2 - 5 } & Scopus & Web of Science & Scopus & Web of Science \\
\hline Framework & 442 & 484 & 227 & 320 \\
\hline Theory & 313 & 189 & 175 & 133 \\
\hline Case study & 352 & 199 & 173 & 116 \\
\hline Measurement & 110 & 80 & 55 & 53 \\
\hline Performance & 570 & 599 & 302 & 382 \\
\hline Supplier selection & 102 & 188 & 61 & 129 \\
\hline
\end{tabular}

Source: own elaboration.

It can therefore be concluded from the analysis of literature and publication databases that the main directions of development and research areas related to SSCM in recent years relate to: theoretical aspect (including framework and definition), measurement (chain itself and its functioning), performance (economic, social and environmental performance), case study presentation and supplier selection processes (taking into account sustainability aspects). Multi-criteria methods, descriptive and mathematical analysis and statistics are most commonly used in research, often creating econometric models for sustainable supply chain research (Table 2). Quantitative testing methods may include: content analysis, AHP, MCDA, factor analysis, sensitivity analysis, cross-case analysis and, survey, modelling, conceptual theory or literature review.

\subsection{Sustainable supply chain management - future (towards of the research area)}

Today's organisations must accept the element and principles of sustainable development, while implementing them along their supply chains as part of a longterm strategy to be part of a competitive advantage. The complexity of the research 
topic is indicated not only by the number of publications but also by the thematic areas, the lack of clarity of definition, the division into social, economic and economic dimensions, the need to take into account the interests of different stakeholders, as well as the transparency of relations between supply chain participants (Bubicz, 2019).

Elkington's research indicates that all areas of sustainable development based on the 3BL principle should be equally implemented in organisations and later in their supply chains. However, practice and relevant literature analysis indicate that this is not common practice. Research confirms the implementation of environmental and economic elements and aspects into supply chains and a sustainable strategy. On the other hand, interest in the social aspect has been shown only recently (Bubicz, 2019). On this basis, it can be pointed out that one of the future directions of research will be a greater emphasis on social aspects, while at the same time being linked to the other two areas. Literature research indicates that social interest in the supply chain has only appeared since around 2008, regarding CSR, S_LCA, social footprint, list of indicators, and framework. The basis is the four main aspects of the social dimension (human rights, labour practices and proper work, society, product responsibility).

The analysis based on scientific articles leads to the conclusion that the further development of the concept related to the implementation of sustainable development principles is and will be increasingly based on the development of research models for the optimisation and evaluation of the performance of the activities. Models for SSCM analysis must be based on three dimensions of sustainable development, and all three areas must be examined together. The economic and environmental dimensions can be studied through environmental practice and strategy, and the development and implementation of social indicators in performance measurement must be related to social aspects. These indicators should be defined in accordance with the principles of corporate social responsibility (Wichaisri and Sopadang, 2018). Decisions in the supply chain should be made considering economic value, environmental protection and stakeholder requirements and benefits, including stakeholder involvement.

Future SSCM activities can be based on four elements (Silvestre, 2016): Sustainable Supply Chain Drivers and Barriers, Sustainable Supply Chain Genesis, Sustainable Supply Chains and Innovation, and Supply Chain Sustainability Trajectories. It can therefore be concluded that both the barriers and drivers are the driving forces behind the interest in this innovative business strategy. The diversity of supply chains contributes to variability in terms of risks, opportunities and barriers. Pioneers and pro-active individuals working actively for sustainable development will be the most courageous and frequent decision-makers in the implementation of the sustainability strategy. They will give other units the stimulus to take action on the one hand, and on the other hand they will set requirements (including 3BL). 
Innovation can also be the driving force behind the new strategy and SSCM research will also be heading in this direction. This is also linked to the context of integration and cooperation in supply chains, defined as dynamic systems that evolve towards more sustainable structures in a continuous process that requires evolutionary and multidirectional changes.

On the one hand, the need to consider all elements as complementary and integrated to each other as building blocks for sustainable supply chain management is highlighted (Carter and Easton, 2011) (see Figure 1) On the other hand, some authors indicate that the environmental aspect will be the dominant logic of considerations (Montabon, Pagell, and Wu, 2016), whilst using the win-win strategy (see Figure 2).

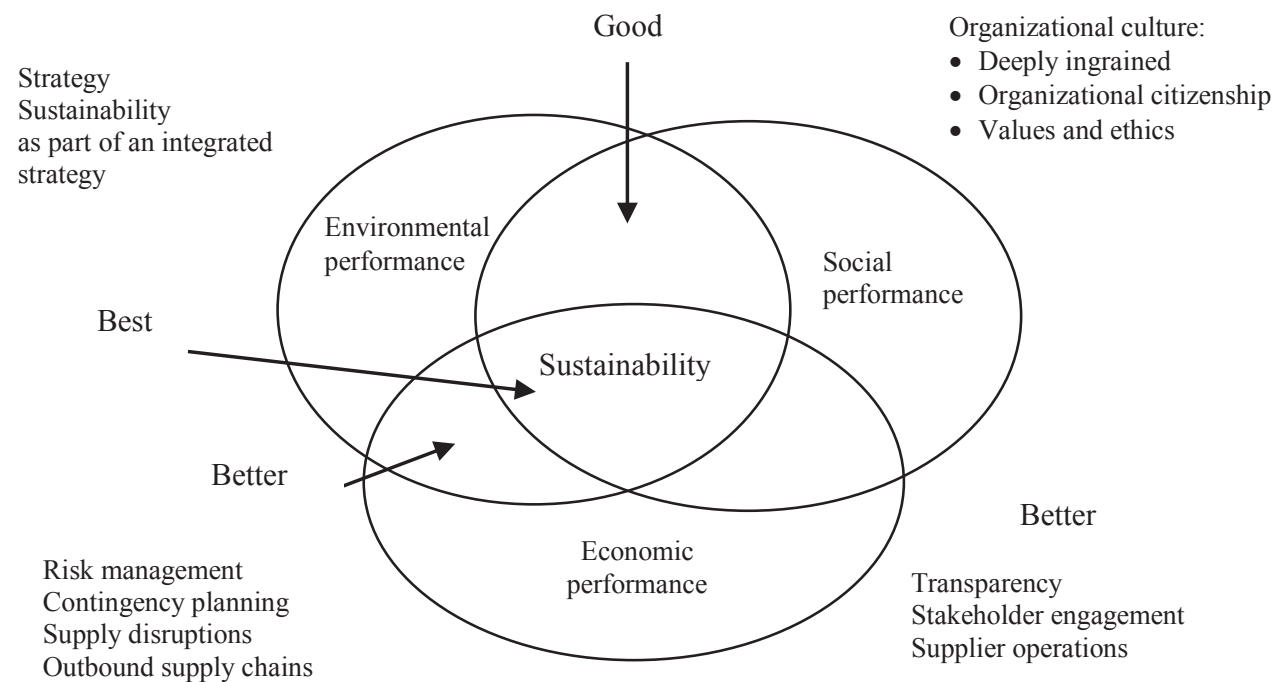

Fig. 1. Sustainable supply chain management

Source: (Carter and Easton, 2011).

In turn, as a future direction of research (Bubicz, 2019) indicate incorporating social aspects pointing out that this is by far the most neglected area in research and that SSCM research should be devoted to it in the coming years and that it is an aspect that complements the proper implementation of the $3 \mathrm{BL}$ principles in the concept of a sustainable supply chain.

Certainly, from the environmental point of view, issues related to the emission of harmful substances into the atmosphere or waste management will be of great importance in future research (Arampantzi and Minis, 2017). The application of management theory and its use to create sustainable supply chains will also play a major role in research (Carter, and Washispack, 2018). Other areas of interest in 


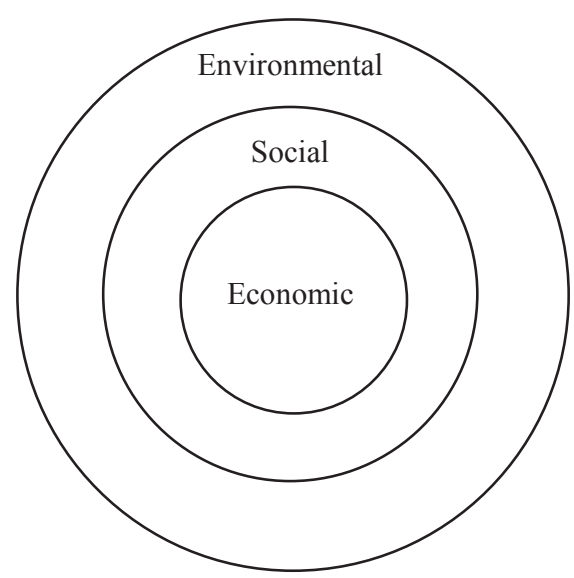

Fig. 2. New logic of sustainable supply chain management - environmental dominance Source: (Montabon, Pagell, and Wu 2016).

SSCM aspects of future research, including its evaluation, include issues related to SSCM: logistics, reverse logistics, performance assessment, production, supplier selection and relations, human resource management, IT systems (Sahu, Narang, Rajput, and Sahu, 2018; Singh and Trivedi, 2016). Sustainable supply chain management practices show that addressing social issues can include: application of CSR codes, ethical treatment of employees and contractors, and not employing children.

Taking into account 3BL, each of the elements is of interest to SSCM researchers. Some of the areas are more exposed, others less so, but when creating and indicating the directions for the further development of SSCM it must be said that the balancing has to take into account these elements.

From the point of view of quantitative research, more and more multi-criteria methods are being used more and more often, and this is an observable trend indicating the direction in which scientific research will develop.

The following are also indicated as future directions of development (Panigrahi, Bahinipati, and Jain, 2018):

- the integration of social issues into the environmental and economic aspect of SSCM;

- lifecycle analysis and the concept of closed-loop SCs for a connected view of sustainability in SCs;

- addressing the issues of inventory management within sustainable SCs (as the traditional inventory models focus on economic aspects). 


\section{Methodology and data collection}

The methodology used in the considerations was based on the literature review. The research was carried out using content analysis. The research process was conducted and consisted of two steps: (i) identifying the literature to study, by a search in databases combined with a set of rules for selecting the relevant pieces of literature, and (ii) mapping the content of the selected literature by extracting information of existing words and the relationships between them.

\subsection{Identifying literature - steps of the research process and limitations}

The research process were adopted as a 4-step research model (Seuring and Müller, 2008; Mayring, 2003), which included: (1) material collection; (2) descriptive analysis; (3) category selection; (4) evaluation of the material. This detailed analysis of sustainable supply chain management publications used a descriptive, qualitative content analysis design with conventional content analysis. The publications were searched for in the Web of Science and Scopus databases, where "sustainable supply chain management" were used in their title, abstract or keywords. The literature review covered the period 2000-2019, and the evaluation and interpretations of research material was based on the VOSViewer tool.

The aim of the considerations was to present the general issues related to the implementation of the principles of sustainable development to the supply chain strategy, in its theoretical aspect, based on the available literature. It did not refer specifically to individual areas (social, environmental and economic). This aspect can be taken into account in the future when considering the subject matter of sustainability. In the analyses, the most frequently used publications were those meeting the requirements defined by the boundary conditions of the research.

\subsection{Data collection and analytical process}

The data for bibliometric analysis were collected in August 2019, therefore the analysis was limited to this period only. The Web of Science and Scopus databases were taken into account in the analysis process. The visualization of the conducted study was to indicate the links and connections between selected factors and specific groups of words, authors, affiliations or geographical location of the research. The database included 777 publications from the Scopus database and 582 publications from the Web of Science database. The research was limited to the following terms: "sustainable supply chain" and "sustainable supply chain management". The test was carried out according to the key: "abstract", "title" and "keywords" - Scopus database, and "author" and "title", "abstract", "source" in the Web of Science. Repeat publications were eliminated (only one source was used). 
The considerations began with a descriptive analysis, indicating the number of citations of individual authors and the number of documents that matched thematically and were included in the analysed database. The selected documents were quoted 24109 times (Scopus), 19964 (without quotes 15000), (Web of Science). The most frequently quoted authors were S. Seuring, M. Pagell, J. Sarkis, C. Searcy and Z. Wu.

Analysing the bibliometric data, Figure 3 indicates the authors with the highest number of publications ( $>7$, Scopus). Seuring and Sarkis have the highest number of publications, as already indicated, they also belong to the most quoted authors (Figure 3).

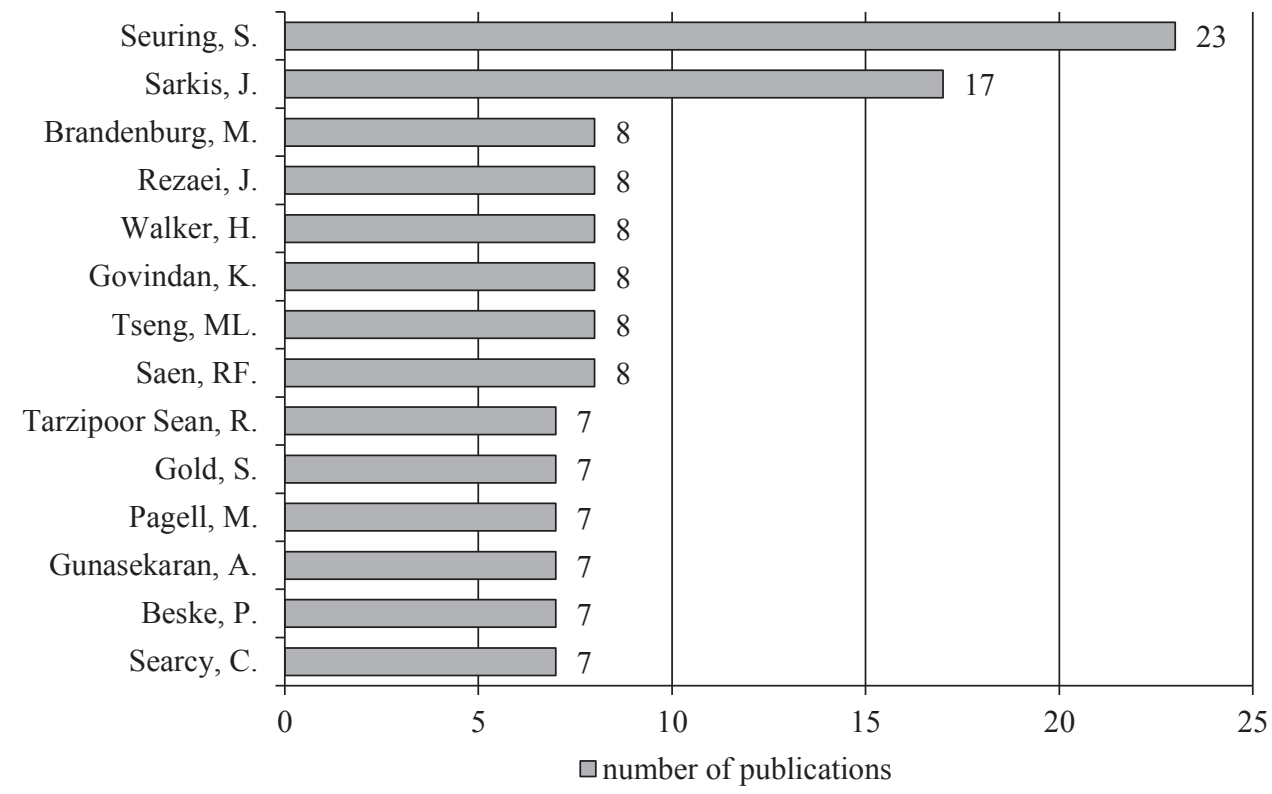

Fig. 3. The authors with the highest number of publications

Source: own elaboration.

The authors come from many countries, but the most frequently published topics in the study are by researchers from the United Kingdom, USA and Germany, while the position of Chinese scientists is becoming increasingly stronger. These data are also confirmed by the authors' affiliations (Table 3).

The most frequently chosen sources of literature published in the SSCM field are JoCP, Sustainability and Supply Chain Management (Table 4).

For more detailed analyses, the VOSViewer tool was used, showing authors' cooperation map and strength of connections (Figure 4 and Figure 5). 
Table 3. Author's affiliations and documents by country

\begin{tabular}{|l|c|l|c|}
\hline \multicolumn{1}{|c|}{ Author affiliations } & Documents & \multicolumn{1}{c|}{ Country } & $\begin{array}{c}\text { Documents } \\
>30\end{array}$ \\
\hline Universität Kassel & 36 & United Kingdom & 112 \\
\hline Islamic Azad University, Karaj Branch & 15 & United States & 102 \\
\hline Worcester Polytechnic Institute & 14 & Germany & 90 \\
\hline Syddansk Universitet & 11 & China & 84 \\
\hline Cardiff University & 11 & India & 75 \\
\hline University of Tehran & 10 & Iran & 51 \\
\hline University of Plymouth & 10 & Canada & 37 \\
\hline Delft University of Technology & 9 & Australia & 36 \\
\hline Hong Kong Polytechnic University & 9 & Italy & 35 \\
\hline University College Dublin & 8 & Brazil & 32 \\
\hline
\end{tabular}

Source: own elaboration.

Table 4. Documents by source

\begin{tabular}{|l|c|}
\hline \multicolumn{1}{|c|}{ Source (journal) } & Documents \\
\hline Journal of Cleaner Production & 88 \\
\hline Sustainability Switzerland & 36 \\
\hline Supply Chain Management & 24 \\
\hline International Journal of Production Economics & 20 \\
\hline Journal of Supply Chain Management & 19 \\
\hline International Journal of Production Research & 17 \\
\hline Resources Conservation and Recycling & 17 \\
\hline Business Strategy and the Environment & 14 \\
\hline International Journal of Operations and Production Management & 12 \\
\hline International Journal of Physical Distribution and Logistics Management & 12 \\
\hline
\end{tabular}

Source: own elaboration.

In interpreting the results obtained, it should be pointed out that this is based on bibliometric data, connections: author and co-authorship, minimum number of documents of an author - 5; it was be found: 1701 authors, 101 meet the thresholds. For each of the 24 authors, the total strength of the co-authorship links with the relevant authors were calculated. The authors with the greatest total link strength were selected. The result of this research gave five clusters: Cluster 1 (4 items Beske, Govindan, Sarkis and Seuring), Cluster 2 (3 items - Lim, Tseng, Wu), Cluster 3 (2 items - Brandenburg and Rebs), Cluster 4 (2 items - Dubey and Gunasekaran) and the last one Cluster 5 (2 items - Pagell, Wu). This looks a little different when 


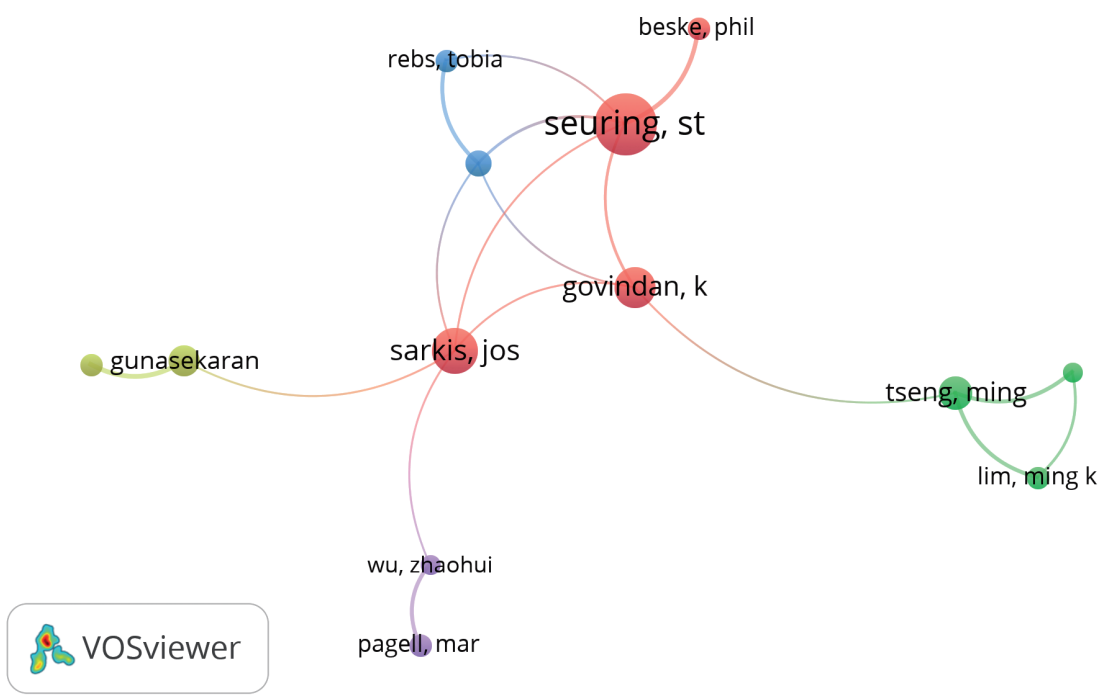

Fig. 4. The strength of links between the authors - the Web of Science

Source: own elaboration.

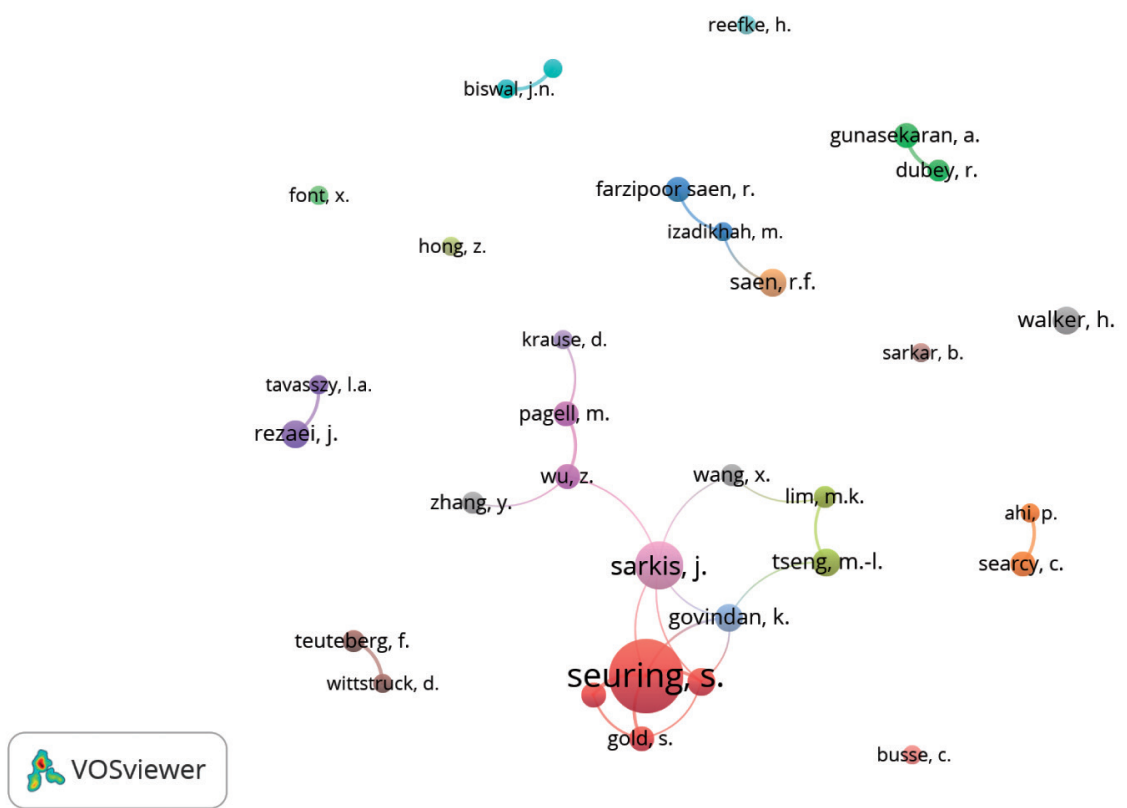

Fig. 5. Links between the authors

Source: own elaboration. 
analysing data from the Scopus database, in this case it can be said (taking into account additional, other publications), that one was dealing with 1555 authors, in conjunction with 32 thresholds, where 32 authors were selected, creating 13 clusters (Figure 5).

In the framework of further analyses, research on the occurrence of block words, titles and isolated terms concerning SSCM and links between individual elements was carried out. In this case, textual data were taken into account.

In the first analysis, titles and words appearing in abstracts were analysed. The following assumptions were made for the analysis: minimum number of occurrences of the term: 10, of the 13423 terms, 416 meet the threshold for these terms, a relevance score was then calculated. Number of terms selected $250-60 \%$ the default choice to the selection of the most relevant terms. As a result of this analysis, five clusters were created, which can be grouped as shown in Figure 6.

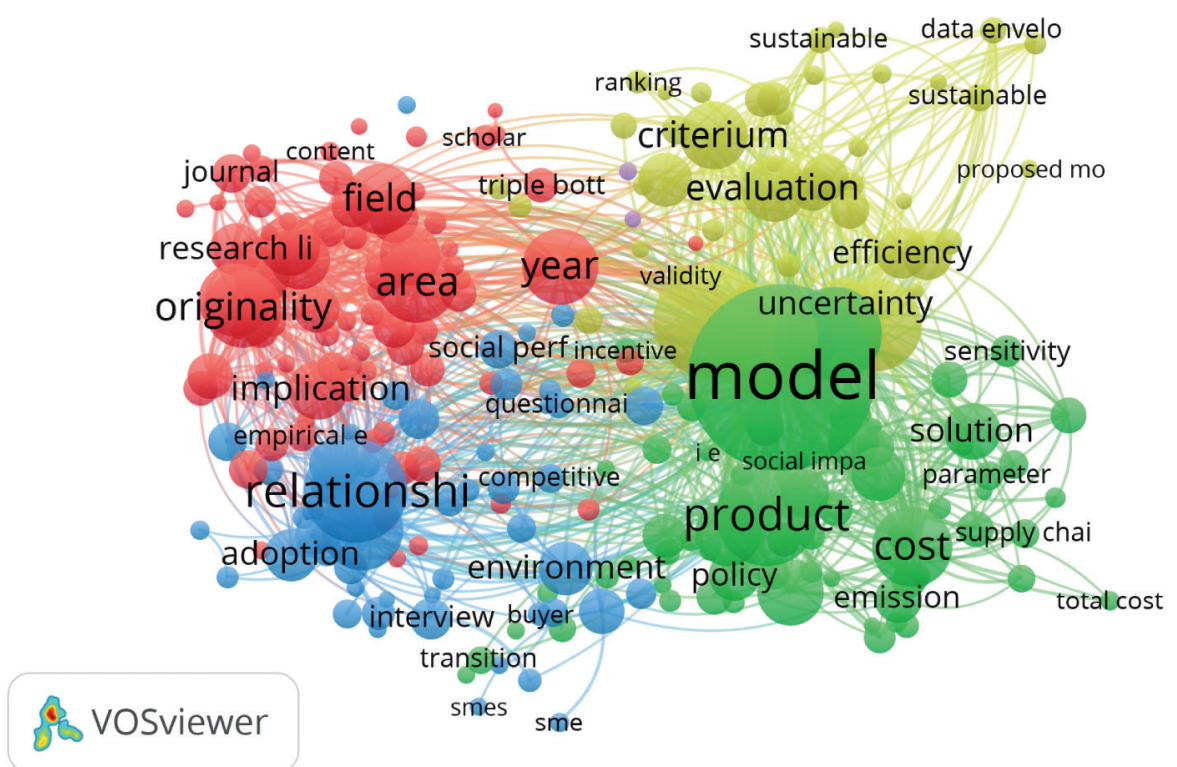

Fig. 6. Analysis of abstracts

Source: own elaboration.

When interpreting the analysis, it can be pointed out that so far the most frequent relationships are related to the models (problem, decision, case study), survey, area, supplier, relationships, environmental performance, relations, and evaluations.

Next, the titles and individual terms that appear in scientific publications were analysed. The visualization is presented in Figure 7, with these assumptions: minimum number of occurrences of the term 5; on the 1704 terms, 23 meet the threshold. For each of the 67 terms, the relevance score was be 40 . From the following 


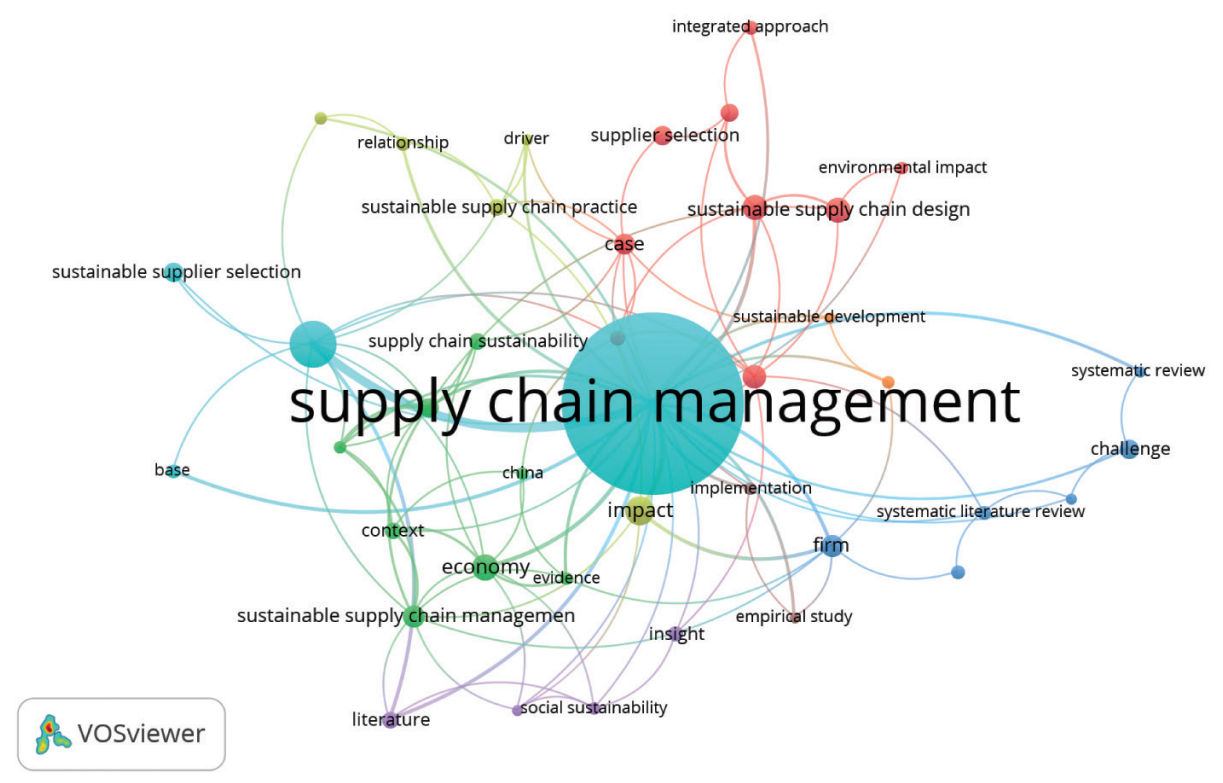

Fig. 7. Terms appearing in the titles of the publications

Source: own elaboration.

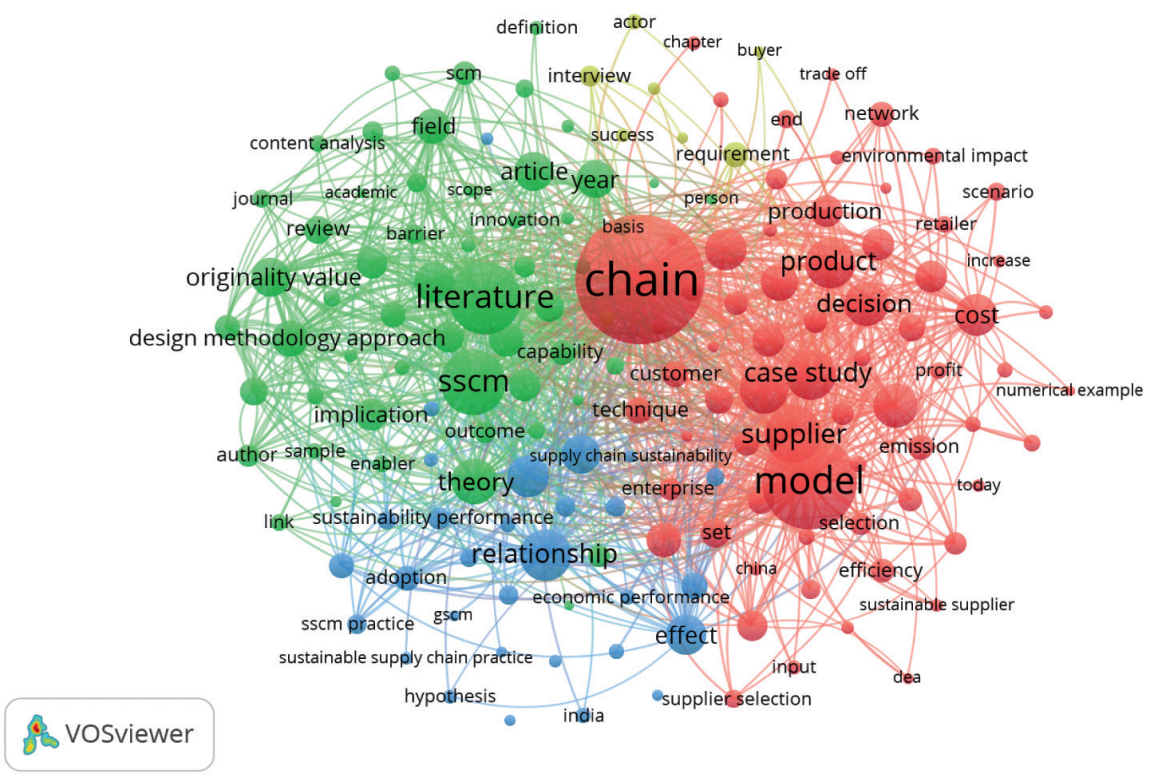

Fig. 8. Connections of the terms in the abstracts

Source: own elaboration. 
analysis the previously indicated terms appeared: supply chain, ssscm, design, relationships, supply chain management, social sustainability, empirical study.

The last analysis refers to the terms appearing in the abstracts. The very nature of an abstract indicates that there are more terms, and so with a minimum number of occurrences of the term 10, one can find 12721 terms, of which 403 meet the threshold. The $60 \%$ relevance items are the 242 items included to the analysis (Figure 8).

It is clear that word relationships are connected with the following concepts: chain, SSCM, SCM, literature, theory, model, supplier.

\section{Results, findings and discussion}

The bibliometric analysis helps to indicate whether, and to what extent, scientists deal with SSCM issues. Analysing the literature in detail, it can be pointed out that the subject matter is becoming more and more important and the interest in this area of research is constantly growing. It is possible to distinguish between development phases and further directions at the same time. It seems that such a wide range of topics and the related research will not lead to the creation of a single definition, but it is necessary to use different sources of scientific knowledge, different fields and authors, as well as practical solutions in order to properly understand the topics and implement their solutions in practice, i.e. to supply chains functioning in global economies. Research, especially bibliometric visualization, shows the vastness of the concepts and issues that SSCM scientists deal with. The main results of these reflections are not only an indication of what has been and is being done in the past, but also an indication of the direction in which the research will change. Just as with the definition area, there is no compliance, whether it will be a social aspect, or environmental, or perhaps all the 3BL principles will be used in the same way to talk about SSCM. As far as the research methods used are concerned, there is a tendency towards thematization of considerations, although if one takes into account the greater emphasis on the social aspect, it seems that the considerations will be more 'soft', also using more qualitative than quantitative methods. The limitation of considerations is probably to focus only on selected concepts and scientific literature, also without referring to and researching with the use of bibliographic methods the case studies or practical solutions, and information that can be obtained from functionally sustainable supply chains. This aspect will be the continuation and continuation of research. The lack of clarity in the definition of concepts as well as in the process and operational scope is a barrier to the implementation of the rules aligned within the supply chain strategy. The multitude of literature in this area also confirms that there are many publications regarding theoretical aspects, but there is no comprehensive research and case study taken from praxis. Practical examples usually relate only to certain ranges or areas of sustainable development. Therefore, it is appropriate to continue exploring these topics in order to unify the area and scope of implementation of the conceptualization. 


\section{Conclusion}

The aim of the paper was to indicate in historical terms (starting with the first publications earlier this century) of how sustainable supply chain management was understood, and what aspects of the research were addressed by the researchers. The bibliometric analysis used also helps to show how complex this matter is, how many elements and terms it covers, and how many disciplines it involves. Both qualitative and quantitative analyses can be used for research in this area, which also allows for the transfer of results and recommendations to business practice. It also appears that SSCM research is still needed and will continue to be needed. The requirements and legal regulations relating to sustainable development, as well as the greater awareness of customers (who are not only customers and the last link in the supply chain, but also participate in it actively, being employees of organisations, operating within the chains) related to the need to protect the environment, but also to strive for social and economic balance, will contribute to the acceptance of the implementation of sustainable development principles to supply chains, even in the event of higher costs or loss of profits. Additionally, in the social aspect, including within society, the most important stakeholders should be seen as the influence on the implementation of changes and setting new directions of SSCM development.

\section{References}

Ahi, P., and Searcy, C. (2013). A comparative literature analysis of definitions for green and sustainable supply chain management. Journal of Cleaner Production, 52, 329-341. https://doi.org/10.1016/j. jclepro.2013.02.018

Ahi, P., and Searcy, C. (2015). An analysis of metrics used to measure performance in green and sustainable supply chains. Journal of Cleaner Production, 86, 360-377. https://doi.org/10.1016/j.jclepro.2014.08.005

Alamdar, S. F., Rabbani, M., and Heydari, J. (2018). Optimal decision problem in a three-level closedloop supply chain with risk-averse players under demand uncertainty. Uncertain Supply Chain Management, (7), 351-368. https://doi.org/10.5267/j.uscm.2018.7.002

Ansari, Z. N., and Kant, R. (2017). A state-of-art literature review reflecting 15 years of focus on sustainable supply chain management. Journal of Cleaner Production, (142), 2524-2543. https://doi. org/10.1016/j.jclepro.2016.11.023

Arampantzi, C., and Minis, I. (2017). Abstract. Journal of Cleaner Production. https://doi.org/10.1016/j. jclepro.2017.03.164

Beske, P., Land, A., and Seuring, S. (2014). Sustainable supply chain management practices and dynamic capabilities in the food industry: a critical analysis of the literature. Intern. Journal of Production Economics, (152), 131-143. https://doi.org/10.1016/j.ijpe.2013.12.026

Brandenburg, M., Govindan, K., Sarkis, J., and Seuring, S. (2014). Quantitative models for sustainable supply chain management: developments and directions. European Journal of Operational Research, 233(2), 299-312. https://doi.org/10.1016/j.ejor.2013.09.032

Bubicz, M. E. (2019). Paper type: literature review. Journal of Cleaner Production. https://doi. org/10.1016/j.jclepro.2019.06.331 
Carter, C. R., and Easton, P. (2011). Sustainable supply chain management: evolution and future directions. International Journal of Physical Distribution \& Logistics Management, 41(1), 46-62. https://doi.org/10.1108/09600031111101420

Carter, C. R., and Rogers, D. S. (2008). A framework of sustainable supply chain management: moving toward new theory. International Journal of Physical Distribution \& Logistics Management, 38(5), 360-387. https://doi.org/10.1108/09600030810882816

Carter, C. R., Rogers, D. S., and Choi, T. Y. (2015). Toward the theory of the supply chain. Journal of Supply Chain Management, 51(2), 89-97.

Carter, C., and Washispack, S. (2018). Mapping the path forward for sustainable supply chain management: a review of reviews. Journal of Business Logistics, 39(4). https://doi.org/10.1111/jbl.12196

Chardine-Baumann, E., and Botta-Genoulaz, V. (2014). A framework for sustainable performance assessment of supply chain management practices. Computers \& Industrial Engineering, (76), 138147. https://doi.org/10.1016/j.cie.2014.07.029

Ciliberti, F., Pontrandolfo, P., and Scozzi, B. (2008). Investigating corporate social responsibility in supply chains: a SME perspective. Journal of Cleaner Production, 16(15), 1579-1588. https://doi. org/10.1016/j.jclepro.2008.04.016

Closs, D. J., Speier, C., and Meacham, N. (2011). Sustainability to support end-to-end value chains: the role of supply chain management. Journal of the Academy of Marketing Science, 39(1), 101-116. https://doi.org/10.1007/s11747-010-0207-4

Das, D. (2017). Development and validation of a scale for measuring sustainable supply chain management practices and performance. Journal of Cleaner Production, (164), 134-1362. https://doi. org/10.1016/j.jclepro.2017.07.006

Faisal, M. N., Al-Esmael, B., and Sharif, K. J. (2017). Supplier selection for a sustainable supply chain: Triple bottom line (3BL) and analytic network process approach. Benchmarking: An International Journal, 24(7), 1956-1976.

Fallahpour, A., Udoncy, E., Nurmaya, S., Yew, K., and Noori, S. (2017). A decision support model for sustainable supplier selection in sustainable supply chain management. Computers \& Industrial Engineering, (105), 391-410. https://doi.org/10.1016/j.cie.2017.01.005

Font, X., Tapper, R., Schwartz, K., and Kornilaki, M. (2008). Sustainable supply chain management in tourism. Business Strategy and the Environment, 17(4), 260. https://doi.org/10.1002/bse.527

Freiboth, H. W. (2018). Corrigendum: investigating supply chain sustainability in South African organisations. Journal of Transport and Supply Chain Management, 0-11. https://doi.org/10.4102/ jtscm.v12i0.437

Fung, R. Y., Morton, B., and Chong, S. (2000). Environmental sustainability in supply chain management. In Proceedings of the 33rd International MATADOR Conference, London: Springer, 35-40.

Ghadimi, P., Dargi, A., and Heavey, C. (2017). Sustainable supplier performance scoring using audition check-list based fuzzy inference system: a case application in automotive spare part industry. Computers \& Industrial Engineering, (105), 12-27. https://doi.org/10.1016/j.cie.2017.01.002

Harms, D., Hansen, E. G., and Schaltegger, S. (n.d.). Strategies in sustainable supply chain management. https://doi.org/10.1002/csr.1293

Hartmann, J., and Moeller, S. (2014). Chain liability in multi-tier supply chains? Responsibility attributions for unsustainable supplier behavior. Journal of Operations Management, 32(5), 281-294. https://doi.org/10.1016/j.jom.2014.01.005

Hassini, E., Surti, C., and Searcy, C. (2012). A literature review and a case study of sustainable supply chains with a focus on metrics. International Journal of Production Economics, 140(1), 69-82. https://doi.org/10.1016/j.ijpe.2012.01.042

Hervani, A. A., Helms, M. M., and Sarkis, J. (2005). Performance measurement for green supply chain management. Benchmarking: An International Journal, (12). https://doi.org/10.1108/ 14635770510609015 
Jaegler, A., and Sarkis, J. (2015). The theory and practice of sustainable supply chains. The Theory and Practice, 8312 (November). https://doi.org/10.1080/16258312.2014.11517329

Karthik, B., Raut, R. D., Kamble, S. S., Kharat, M. G., and Kamble, S. J. (2015). Decision support system framework for performance based evaluation and ranking system of carry and forward agents. Strategic Outsourcing: An International Journal, (8).

Kiousis, V., Nathanail, E., and Karakikes, I. (2019). Assessing traffic and environmental impacts of smart lockers logistics measure in a medium-sized municipality of Athens. Advances in Intelligent Systems and Computing, 879, 614-621. https://doi.org/10.1007/978-3-030-02305-8_74

Kisperska-Moron, D. (2012). Społeczna odpowiedzialność łańcuchów dostaw i ich systemów logistycznych (założenia koncepcyjne). Logistyka, (4).

Koberg, E., and Longoni, A. (2019). A systematic review of sustainable supply chain management in global supply chains. Journal of Cleaner Production, 207, 1084-1098. https://doi.org/10.1016/j. jclepro.2018.10.033

Lu, H., Jiang, S., Song, W., and Ming, X. (2018). A rough multi-criteria decision-making approach for sustainable supplier selection under vague environment, (Mcdm). https://oi.org/10.3390/ su10082622

Mayring, P. (2010). Qualitative inhaltsanalyse. In Handbuch qualitative Forschung in der Psychologie (pp. 601-613). VS Verlag für Sozialwissenschaften., Springer.

Montabon, F., Pagell, M., and Wu, Z. (2016). Making sustainability sustainable. Journal of Supply Chain Management, 52(2), 11-27.

Moreno-Camacho, C. A., Montoya-Torres, J. R., and Jaegler, A. (2019). Sustainability metrics for real case applications of the supply chain network design problem: a systematic literature review. Journal of Cleaner Production, (231), 600-618. https://doi.org/10.1016/j.jclepro.2019.05.278

Pagell, M., and Shevchenko, A. (2009). Why research in sustainable supply chain management should have no future, Journal of supply chain management, 50(1), 44-55.

Pagell, M., and Wu, Z. H. (2009). Building a more complete theory of sustainable supply chain management using case studies of 10 exemplars. Journal of Supply Chain Management, 45(2), 37-56. https://doi.org/10.1111/j.1745-493X.2009.03162.x

Panigrahi, S. S., Bahinipati, B., and Jain, V. (2018). Sustainable supply chain management: a review of literature and implications for future research. Management of Environmental Quality: An International Journal.

Popović, T. (n.a.). Quantitative indicators of social sustainability applicable in process systems engineering. http://urn.fi/URN:ISBN:978-952-335-373-2

Pulkki, R. (2001). Role of supply chain management in the wise use of wood resources. The Southern African Forestry Journal, 191(1), 89-95.

Rajeev, A., Pati, R. K., Padhi, S. S., and Govindan, K. (2017). Evolution of sustainability in supply chain management: a literature review. Journal of Cleaner Production, (162), 299-314. https://doi. org/10.1016/j.jclepro.2017.05.026

Sahu, A. K., Narang, H. K., Rajput, M. S., and Sahu, N. K., (2018). Performance modeling and benchmarking of green supply chain management. Benchmarking: An International Journal, 25(7), 2248-2271. https://doi.org/10.1108/bij-02-2017-0032

Sarkar, S., and Pansera, M. (2017). Technological Forecasting and Social Change Sustainability-driven innovation at the bottom: insights from grassroots ecopreneurs. Technological Forecasting \& Social Change, (114), 327-338. https://doi.org/10.1016/j.techfore.2016.08.029

Sasikumar, P., and Kannan, G. (2009). Issues in reverse supply chain, part III: classification and simple analysis. International Journal of Sustainable Engineering, 2(1), 2-27.

Schaltegger, S., Burritt, R., Beske, P., and Seuring, S. (2014). Putting sustainability into supply chain management. Supply Chain Management: An International Journal.

Schwartz, K., Tapper, R., and Font, X. (2008). A sustainable supply chain management framework for tour operators. Journal of Sustainable Tourism, 16(3), 298-314. 
Seuring, S. (2008). Assessing the rigor of case study research in supply chain management. Supply Chain Management: An International Journal, 13(2), 128-137.

Seuring, S., and Müller, M. (2008). Core issues in sustainable supply chain management - a Delphi study. Business Strategy and the Environment, 17(8), 455-466.

Seuring, S., and Müller, M. (2008). From a literature review to a conceptual framework for sustainable supply chain management. Journal of Cleaner Production, 16(15), 1699-1710. https://doi. org/10.1016/j.jclepro.2008.04.020

Silvestre, B. (2016). Sustainable supply chain management: current debate and future directions. Gestão \& Produção, 23(2), 235-249. https://doi.org/10.1590/0104-530x2202-16

Singh, A., and Trivedi, A. (2016). Sustainable green supply chain management: trends and current practices. Competitiveness Review, 26(3), 265-288.

Spetic, W., Marquez, P., and Kozak, R. (2012). Critical areas and entry points for sustainability-related strategies in the sugarcane-based ethanol industry of Brazil. https://doi.org/10.1002/bse.1727

Tajbakhsh, A., and Hassini, E. (2015). Performance measurement of sustainable supply chains: a review and research questions. International Journal of Productivity and Performance Management, 64(6), 744-783.

Touboulic, A., and Walker, H. (2015). Theories in sustainable supply chain management: a structured literature review. Journal of Service Management, 45(1-2), 16-42. https://doi.org/10.1108/MBE09-2016-0047

Tseng, M., Lim, M., and Wong, W. P. (2015). Sustainable supply chain management. Industrial Management \& Data Systems, 115(3), 436-461. https://doi.org/10.1108/IMDS-10-2014-0319

Tundys, B., (2018). Zielony tańcuch dostaw. Zarzqdzanie, pomiar, ocena. Warszawa: CeDeWu.

Tundys, B., Rzeczycki, A., Zioło, M., and Jankowski, J. (2014). Models of an integrated performance measurement system of intelligent and sustainable supply chains. Lecture Notes in Computer Science (including subseries Lecture Notes in Artificial Intelligence and Lecture Notes in Bioinformatics) (Vol. 8398 LNAI). https://doi.org/10.1007/978-3-319-05458-2_52

Tundys, B., and Wiśniewski, T. (2018). The selected method and tools for performance measurement in the green supply chain-survey analysis in Poland. Sustainability (Switzerland), 10(2). https://doi. org/10.3390/su10020549

Varsei, M., and Polyakovskiy, S. (2017). Sustainable supply chain network design: a case of the wine industry in Australia. Omega, (66), 236-247. https://doi.org/10.1016/j.omega.2015.11.009

Wichaisri, S., and Sopadang, A. (2018). Trends and future directions in sustainable development, 17 (May 2017), 1-17. https://doi.org/10.1002/sd.1687

Wolf, J. (2011). Sustainable supply chain management integration: a qualitative analysis of the German manufacturing industry. Journal of Business Ethics, 102(2), 221-235. https://doi.org/10.1007/ s10551-011-0806-0

Wu, C., and Barnes, D. (2015). An integrated model for green partner selection and supply chain construction. Journal of Cleaner Production, (112), 2114-2132. https:// doi:10.1016/j.jclepro.2015.02.023

Wu, Z., and Pullman, M. E. (2015). Cultural embeddedness in supply networks. Journal of Operations Management, (37), 45-58. https://doi.org/10.1016/j.jom.2015.06.004

Zahiri, B., Zhuang, J., and Mohammadi, M. (2020). Toward an integrated sustainable-resilient supply chain: a pharmaceutical case study. Transportation Research Part E, 103(2017), 109-142. https:// doi.org/10.1016/j.tre.2017.04.009

Zhou, X., and Xu, Z. (2018). An integrated sustainable supplier selection approach based on hybrid information aggregation. https://doi.org/10.3390/su10072543 